\title{
Respiratory illness caused by overheating of polyvinyl chloride
}

\author{
BRIGITTE FRONEBERG, P L JOHNSON, AND P J LANDRIGAN \\ From the National Institute for Occupational Safety and Health, Robert A Taft Laboratories, Cincinnati \\ $\mathrm{OH} 45226$, USA
}

\begin{abstract}
On 9 August 1979, $62(30.8 \%)$ of 201 workers and one of 60 management personnel in a polyvinul chloride (PVC) fabricating plant developed acute upper and lower respiratory irritation, headache, nausea, and fainting. All were taken to hospital; none died. Sixty of the patients were women. Interviews two weeks later with 57 affected and 14 unaffected workers disclosed that illness had followed exposure to fumes from an overheated $\left(362^{\circ} \mathrm{C}\right) \mathrm{PVC}$ extruding machine. Fumes were emitted from 1100 until 1150; cases occurred from 1100 until late afternoon. All workers who became ill worked west of the overheated extruder, and the affected manager had visited that area. The earliest cases occurred closest to the machine, and incidence decreased (from $53.3 \%$ to $15.4 \%$ ) with distance westward. This pattern was consistent with plant ventilation. Incidence rates in men and women did not differ $(\mathrm{p}>0 \cdot 1)$. At two and 14 weeks, pulmonary function testing of workers with persistent pulmonary symptoms showed abnormalities in 13 of 16 and in 9 of 11 respectively; the group with persistent symptoms contained an excess of non-smokers and of those with previous respiratory illnesses. One kilogram of $\mathrm{PVC}$ heated to $300^{\circ} \mathrm{C}$ releases an estimated $12.9 \mathrm{~g}$ of hydrochloric acid $(\mathrm{HCl})$ and $4.9 \mathrm{~g}$ of carbon monoxide $(\mathrm{CO})$. We attributed the outbreak to exposure to toxic $\mathrm{HCl}$ and $\mathrm{CO}$ and rejected the hypothesis of mass psychogenic illness.
\end{abstract}

Polyvinyl chloride (PVC) is a plastic used widely as an insulating material, as a substitute for rubber, and for thousands of consumer products from car equipment to pipes, phonograph records, and baby pants. It is formed from vinyl chloride monomer by addition polymerisation. Since PVC resin is tough and brittle with poor heat stability, fabrication of PVC into commercial products usually entails the "compounding" of PVC' with other chemicals (plasticisers, stabilisers, fillers, pigments, lubricants, and modifiers) to produce the desired properties; such additives may constitute up to $60 \%$ of total weight in some finished PVC plastics. These plastics are usually formed into products by milling, calendering, and extrusion moulding.

PVC is thermally stable at temperatures below $225^{\circ} \mathrm{C}$. Its ignition temperature is $475^{\circ} \mathrm{C}$. Between $225^{\circ} \mathrm{C}$ and $475^{\circ} \mathrm{C} \mathrm{PVC}$ will not burn but will degrade thermally, releasing first hydrochloric acid $(\mathrm{HCl})$ and then, above $300^{\circ} \mathrm{C}$, carbon monoxide (CO), carbon dioxide $\left(\mathrm{CO}_{2}\right)$, benzene, and vinylchloride monomer. ${ }^{12}$ Above $600^{\circ} \mathrm{C}$, small amounts of

Received 5 November 1980

Accepted 13 October 1981 phosgene and chlorine are formed. ${ }^{1}$ Many additional degradation products may be released from PVC additives.

Occupational exposure to thermal degradation products of PVC has been reported to produce acute and chronic illness. Carbon monoxide poisoning may occur in acute exposure. Acute exposure to corrosive $\mathrm{HCl}$ fume from $\mathrm{PVC}$ resins has been shown in firefighters to cause laryngitis, glottal oedema, bronchitis, pulmonary oedema, and death..$^{1-3}$ Prolonged exposure to $\mathrm{HCl}$ fume, phosgene, chlorine, and the degradation products of PVC additives is thought to contribute to the aetiology of "meat wrapper's asthma."4-9

We describe the epidemiological and clinical features of an outbreak of acute respiratory illness that followed a single exposure to fumes from overheated PVC.

\section{The outbreak}

The outbreak occurred on 9 August 1979 in a PVC fabricating plant. The major products of the plant were automotive switches, horns, and windshield wipers. Production took place in one long rect angular 
workroom without partitions or exhaust ventilation; an office building was separate. At the time of the outbreak there were 201 dayshift workers and 60 management personnel at the plant. The plant operated in three shifts.

At 1100 am on 9 August an extruding machine in the centre of the plant overheated from $148^{\circ} \mathrm{C}$ to $338^{\circ} \mathrm{C}$ and started to release heavy irritant fumes into the workroom. Soon workers closest to the machine began to complain of burning eyes, sore throat, and difficulty in breathing.

Because of the lack of ventilation the fumes dispersed to the west side of the workroom and accumulated there. Workers were kept in production lines despite their complaints and were supplied with wet cloths to cover their faces. They were dismissed for lunch in two shifts from 1130 until 1220 . During the lunch period, between 1150 and 1200 , the overheated extruder was finally shut down. Two overhead doors along the western side of the workroom were, however, closed, and fans were set up in the far west corners of the building to blow the fumes back towards the centre of the plant.

After workers returned from lunch to the lines the situation worsened rapidly. The fumes had apparently been pushed by the fans to the area near the overheated extruding machine. At 1235 a worker collapsed; three or four others followed immediately, and all were sent to hospital. At 1300 the areas close to the extruder were evacuated. The workers, although they had been sent outside, continued to fall ill and to faint on the lawn and were taken to hospital. At 1400 all workers were sent home. The plant was thoroughly ventilated. During the next shift, which began at 1500 , no workers fell ill or complained of symptoms. There was no further recurrence of illness.

Altogether, the extruder had emitted smoke from about 1100 to 1150 , and workers were exposed for 1.5 to 2.5 hours, depending on lunchbreak schedules. A total of 62 workers and one manager fell ill. All were taken to a hospital for observation; all were discharged within hours. All but two cases occurred in women, three of whom were pregnant.

The managers of the plant regarded the event as mass hysteria. Workers and local union representatives thought, however, that more than fear and anxiety were involved and insisted on investigation. An evaluation of the episode was, therefore, conducted by the National Institute for Occupational Safety and Health (NIOSH).

\section{Methods}

MEDICAL

On 23/24 August 1979 one NIOSH investigator (BF) interviewed $57(92 \%)$ of those taken to hospital from the plant, using a questionnaire to record age, sex, seniority, and marital and parental status, as well as information on time of onset of illness, work station at the time of onset, symptomatology, and duration of symptoms. In addition the questionnaire was specifically designed to elicit data on indicators of job dissatisfaction such as boredom, unwanted overtime, inadequate supervisory or peer support, and production pressure; several of these questions were taken from a NIOSH questionnaire developed for the evaluation of mass hysteria. ${ }^{10}$ Fourteen exposed but unaffected workers were interviewed at the same time, as controls. Hospital records of all 62 workers sent to hospital were obtained and evaluated.

Pulmonary function tests (PFT) were performed at the initial evaluation on 16 workers with persistent respiratory complaints. Eleven with abnormal PFT results according to the criteria used ${ }^{11}$ received a second test on 26 November 1979. These second test readings were compared with those of a group of matched controls from the same work areas; matching was on sex, race, and age (within \pm three years). Both groups answered a shortened form of the American Thoracic Society questionnaire.

INDUSTRIAL HYGIENE

Air samples for measuring PVC decomposition products $\left(\mathrm{HCl}, \mathrm{CO}, \mathrm{CO}_{2}\right.$, phosgene, chlorine, and vinyl chloride monomer) were obtained on 23/24 August by means of detector tubes. There were no visible fumes in the workroom on those days.

Bulk pellets of PVC resin were collected at the plant on 23 August and were analysed at NIOSH laboratories for thermal degradation products at temperatures of $300-450^{\circ} \mathrm{F}\left(148-232^{\circ} \mathrm{C}\right)$ and 500 $600^{\circ} \mathrm{F}\left(260-315^{\circ} \mathrm{C}\right)$. Analyses were performed by gas chromatography/mass spectroscopy techniques.

\section{Results}

\section{EPIDEMIOLOGY}

We interviewed $57(90.5 \%)$ of the 63 people taken to hospital. The three who were pregnant were excluded from further analysis.

The principal symptoms were dry mouth $(75 \%)$, headache $(67 \%)$, dizziness $(63 \%)$, and lightheadedness $(58 \%)$ (table 1$)$. Chest tightness was experienced by $56 \%$ of those interviewed, dyspnoea by $46 \%$, and chest pain by $31 \%$.

Onset of the outbreak was abrupt. No cases occurred before 1100,24 occurred from 1100 to 1200 noon, 21 from noon until 1400 and nine had later onset at home. The onset of illness varied with distance from the overheated extruder: more 
Table 1 Incidence of symptoms in affected workers. (Percentage of interviewed cases with symptom in parentheses)

\begin{tabular}{|c|c|c|c|}
\hline $\begin{array}{l}\text { A } \\
\text { Central nervous system } \\
\text { depression }\end{array}$ & $\begin{array}{l}\text { B } \\
\text { Mucous membrane effects }\end{array}$ & $\begin{array}{l}\text { C } \\
\text { Respiratory tract irritation }\end{array}$ & $\begin{array}{l}\text { D } \\
\text { Miscellaneous }\end{array}$ \\
\hline $\begin{array}{l}\text { Severe headache (67) } \\
\text { Blurred vision (10) } \\
\text { Vertigo (63) } \\
\text { Lightheadedness (58) } \\
\text { Weakness (62) } \\
\text { Numbness (50) } \\
\text { Sleepiness (37) } \\
\text { Convulsive laughter (2) } \\
\text { Fainting (7) }\end{array}$ & $\begin{array}{l}\text { Burning eyes (42) } \\
\text { Lacrimation (12) } \\
\text { Dry mouth (75) }\end{array}$ & $\begin{array}{l}\text { Sore throat (39) } \\
\text { Hoarseness (12) } \\
\text { Cough (37) } \\
\text { Dyspnoea (46) } \\
\text { Chest tightness (56) } \\
\text { Chest pain (31) } \\
\text { Feeling of suffocation (29) }\end{array}$ & $\begin{array}{l}\text { Chills (39) } \\
\text { Bitter taste (46) } \\
\text { Difficulty swallowing (29) } \\
\text { Nausea (35) } \\
\text { Vomiting (6) } \\
\text { Abdominal pain (8) } \\
\text { Muscle soreness (6) } \\
\text { Racing heart (2) }\end{array}$ \\
\hline
\end{tabular}

Table 2 Distribution of cases by work area

\begin{tabular}{|c|c|c|c|c|}
\hline Location & $\begin{array}{l}\text { Mean distance }(m) \\
\text { west of extruder }\end{array}$ & $\begin{array}{l}\text { No of } \\
\text { workers }\end{array}$ & $\begin{array}{l}\text { No }(\%) \\
\text { cases }\end{array}$ & $\begin{array}{l}\text { No }(\%) \\
\text { severe cases }\end{array}$ \\
\hline $\begin{array}{l}\text { Subassembly } \\
\text { Area } 700 \\
\text { Area } 660 \\
\text { Areas } 560,580,600 \\
\text { Areas } 500,520 \text {, lunchroom, noiseroom } \\
\text { Warehouse, moulding, paint room }\end{array}$ & $\begin{array}{l}10 \\
25 \\
40 \\
55 \\
80 \\
\text { East and north }\end{array}$ & $\begin{array}{r}15 \\
5 \\
52 \\
55 \\
26 \\
48\end{array}$ & $\begin{array}{r}8(53 \cdot 3) \\
3(60 \cdot 0) \\
24(46 \cdot 1) \\
23(41 \cdot 8) \\
4(15 \cdot 4) \\
0(-)\end{array}$ & $\begin{array}{l}4(26 \cdot 7) \\
3(60 \cdot 0) \\
4(7 \cdot 7) \\
5(9 \cdot 1) \\
0(-) \\
0(-)\end{array}$ \\
\hline Total & - & 201 & $62 \dagger(30.8)$ & $16(7 \cdot 9)$ \\
\hline
\end{tabular}

* Severe cases had persistent respiratory symptoms.

tAn additional case occurred in a manager.

than half of the cases close to the extruder occurred between 1100 and 1200, whereas more than half of the cases further down the line occurred between 1200 and 1400 or even later $(p<0.01)$.

Sixty-two of the 63 cases occurred in workers whose work stations at onset of illness were in the western section of the plant (table 2). No cases occurred east of the overheated extruder. Attack rates were highest close to the extruder and decreased with distance westward (table 2). One case occurred in a manager employed in the warehouse, north of the main plant. During the outbreak he had visited his daughter, who worked in the western section of the plant.

Illness occurred in one out of five maintenance workers. Although their base was located in the eastern section of the plant, they were working west of the overheated extruder at the time of the outbreak.

Illness occurred much more frequently in women than in men, but the number of men employed was too small for this difference to reach statistical

Table 3 Incidence rates among exposed workers by sex

\begin{tabular}{lccl}
\hline & No of workers & No affected & Rate $(\%)$ \\
\hline Men & 9 & 2 & $22 \cdot 3$ \\
Women & 148 & 60 & $40 \cdot 5$ \\
Total & 157 & $62^{*}$ & $39 \cdot 5$
\end{tabular}

$\chi^{2}=2 \cdot 2237$.

$0.2<\mathrm{p}<0.1$.

* An additional case occurred in a manager. significance at the $5 \%$ level (table 3 ).

Comparison between affected and non-affected groups indicated that they were comparable in age, seniority, marital status, and number of dependants. The prevalence of current smoking was lower in those with symptoms than in those who developed no symptoms during the outbreak $(p<0.001)$. The affected group rated their state of general health lower than did the unaffected $(0.1>p>0.05)$ and reported that they had suffered more often than the unaffected from nervousness, loneliness, upset stomach, headache, faint feelings, and fatigue before the outbreak $(\mathrm{p}<0.05)$. The affected group did not, however, have a higher frequency of past absenteeism. Both groups worked 40 hours a week, none did overtime work, and only two had other paid employment. They showed no significant differences in their attitudes towards their jobs; most liked their jobs and colleagues and expressed satisfaction with the management/worker relationship and with their income. Both groups, however, expressed discontent with working conditions such as poor ventilation and the lack of a safety programme.

Examination of hospital records showed that the examining doctors had attributed workers' signs and symptoms largely to anxiety. All 41 radiographs obtained were normal or showed unrelated findings; three ECGs were also normal. One of two blood gas analyses was normal, the other showed respiratory alkalosis consistent with hyperventilation. 
PULMONARY FUNCTION TESTING

Most ill workers recovered within hours. Sixteen, however, had persistent respiratory symptoms that were still evident at the time of evaluation. Seven of those 16 clustered in the two plant areas closest to the over-heated extruder (table 2). Pulmonary function tests were administered to the 16 with persistent respiratory complaints by means of a dry wedge spirometer (Vitalograph).* Thirteen of the 16 showed pathological results (table 4). Only five $(38 \%)$ of those with abnormal results smoked.

Repetition of ventilation tests in late November on 11 of the 13 workers who had abnormal lung function in the initial testing showed persistence of abnormal function in nine (3 obstructive, 6 restrictive). Overall, the indicators for obstructive and restrictive lung disease had, however, improved slightly. Compared with matched controls from the same work areas, cases evaluated in November had significantly poorer lung function $(p<0.05)$. They also reported significantly more experience of respiratory illness (bronchitis, pneumonia, asthma) before their exposure to fumes in the present episode $(p<0.05)$.

Table 4 Results of pulmonary function testing (Vitalograph) of workers with respiratory symptoms

\begin{tabular}{lllc}
\hline & Smoker & Non-smoker & Total \\
\hline Normal function & 1 & 2 & 3 \\
Obstructive defect & 1 & 1 & 2 \\
Restrictive defect & 1 & 5 & 6 \\
Combined obstructive/ & 2 & 3 & 5 \\
$\quad$ restrictive defect & 5 & 11 & 16 \\
\hline Total & & & \\
\hline
\end{tabular}

A ventilation defect was considered obstructive when either $F_{E V}$ was less than $80 \%$ of predicted or the ratio of $\mathrm{FEV}_{1} / \mathrm{FVC} \%$ was less than $70 \%$; it was considered restrictive when FVC was less than $80 \%$ of predicted. ${ }^{11}$

\section{INDUSTRIAL HYGIENE}

Sampling at the plant on $23 / 24$ August showed no detectable concentrations of $\mathrm{CO}, \mathrm{CO}_{2}, \mathrm{HCl}$, phosgene, or chlorine. Vinyl chloride monomer was, however, detected in air at concentrations between 0.45 and $1.3 \mathrm{ppm}$.

Thermal degradation testing of two types of bulk PVC samples from the plant at temperatures of $300-450^{\circ} \mathrm{F}\left(148-232^{\circ} \mathrm{C}\right)$ showed release of long-chain aliphatic alcohols, toluene, benzene, various chlorinated species, and a major peak of $\mathrm{HCl}$. Main components released at $500-600^{\circ} \mathrm{F}\left(260-315^{\circ} \mathrm{C}\right)$ were aromatic hydrocarbons such as benzene, phenol, and adipates along with various aliphatic alcohols, alkenes, anhydrides, few of them chlorinated.

* Mention of a company name or product is for information only and does not constitute endorsement by NIOSH.
Carbon monoxide release could not be assessed by the method used.

\section{Discussion}

The major finding in this investigation was that a high proportion of workers exposed to fumes produced by the thermal degradation of PVC resin in an overheated extruder developed symptoms of respiratory irritation and of central nervous system dysfunction (table 1). Although no one died, symptoms were of sufficient severity to require transient hospital care for 63 workers.

Plant management believed initially that the outbreak was caused by psychogenic factors, a belief that was possibly reinforced by the high proportion of women among the affected workers. That hypothesis was, however, abandoned after examination of the spatiotemporal distribution of cases and with the realisation that attack rates did not differ significantly between men and women workers. This experience exemplifies the hazard of too ready acceptance of a psychogenic aetiology for outbreaks of mass industrial illness.

Acute illness similar to that encountered in the present outbreak has been reported in firefighters exposed to burning or smouldering plastic ${ }^{1-3}$ and in workers exposed to fumes from burning PVCcoated wiring. ${ }^{12}$ Also residual pulmonary injury was described in several of the latter group of workers. ${ }^{12}$

In the present investigation we observed a subset of exposed workers, consisting principally of nonsmokers, who exhibited persistence of cough, chest pain, and chest tightness for several weeks after the episode. Those symptoms were associated with persistent spirographic abnormalities, which improved only slightly in the three months following the outbreak. Although the persistent symptoms in those workers were related clearly in their onset to the acute exposure, it is difficult in the absence of previous baseline data to ascribe the spirographic abnormalities to that source. Again, we were surprised to find that many of this group with spirographic abnormalities had restrictive rather than the obstructive changes that have been reported in people, such as meat wrappers, exposed occupationally to the thermal degradation products of PVC. $68 \mathrm{~A}$ possible explanation for the finding is that the group with persistent abnormalities reported a higher prevalence of prior respiratory disease than controls, a finding that may suggest previous background of respiratory illness or a heightened susceptibility to respiratory insult in this subgroup.

Prior studies of thermal degradation of PVC at various temperatures ${ }^{31314}$ have indicated that the major toxic decomposition products released at the 
Table 5 Quantities of substances emitted from $1 \mathrm{~kg}$ $P V C$ at various temperatures ${ }^{3}$

\begin{tabular}{lllll}
\hline $\begin{array}{l}\text { Temperatures } \\
(C)\end{array}$ & \multicolumn{4}{l}{ Quantities of } \\
\cline { 2 - 5 } & $\begin{array}{l}\text { Hydrogen } \\
\text { chloride }\end{array}$ & Phosgene & $\begin{array}{l}\text { Carbon } \\
\text { monoxide }\end{array}$ & $\begin{array}{l}\text { Carbon } \\
\text { dioxide }\end{array}$ \\
\hline $300^{\circ}$ & 12900 & 0 & 4900 & 6800 \\
$600^{\circ}$ & 15300 & 1 & 6900 & 14800 \\
$900^{\circ}$ & 15400 & 3 & 480 & 28700 \\
\hline
\end{tabular}

temperature range encountered in the overheated extruder in this outbreak $\left(362^{\circ} \mathrm{C}\right)$ are $\mathrm{HCl}$ and $\mathrm{CO}$. It has been estimated that at the temperatures encountered in the present episode maximum releases into air of $\mathrm{HCl}$ and $\mathrm{CO}$ from each kilogram of overheated PVC resin would have been $12900 \mathrm{mg}$ and $4900 \mathrm{mg}$ respectively (table 5 ). The concentrations of $\mathrm{HCl}$ and $\mathrm{CO}$ actually achieved in workroom air are, however, not known, because the quantity of resin combusted and the rapidity of dilution cannot be ascertained. It appears likely that in the presence of inadequate ventilation $\mathrm{HCl}$ and $\mathrm{CO}$ could have accumulated to concentrations well above the normally accepted industrial threshold limit values and short-term exposure limits, and that those concentrations of $\mathrm{HCl}, \mathrm{CO}$, and possibly of other degradation products, accounted for the observed illness.

\section{References}

${ }^{1}$ Dyer RF, Esch WH. Polyvinyl chloride toxicity in fires. JAMA 1976;235:393-7.
2 Terrill JB, Montgomery RR, Reinhardt CF. Toxic gases from fires. Science 1978;200:1343-7.

${ }^{3}$ Schmidt, P. Gesundheitsgefahren durch Kunststoffbrande, Unser Brandschutz. Wissensch-technische Beilage 1969; 19:53-8.

4 Falk H, Portnoy B. Respiratory tract illness in meat wrappers. JAMA 1976;235:915-7.

${ }^{5}$ Vandervort R, Brooks SM. Polyvinyl chloride film. Thermal decomposition products as an occupational illness. 1. Environmental exposures and toxicology. JOM 1977;19:188-91.

- Brooks SM, Vandervort R. Polyvinyl chloride film thermal decomposition products as an occupational illness. 2. Clinical studies. JOM 1977;19:192-6.

${ }^{7}$ Sokol WN, Aelony Y, Beall GN. Meat wrapper's asthma a new syndrome. JAMA 1973;226:639-41.

${ }^{8}$ Polakoff PL, Lapp NL, Reger R. Polyvinyl chloride pyrrolysis products a potential cause for respiratory impairment. Arch Environ Health 1975;30:269-71.

9 Polakoff PL, Vandervort R, Flesch JP. Health hazard determination report 72. Cincinnati: US Department of Health, Education, and Welfare, National Institute for Occupational Safety and Health, 1972:53-8.

${ }^{10}$ Colligan MJ, Smith MJ. A metholodological approach for evaluating outbreaks of mass psychogenic illness in industry. JOM 1978;206:401-2.

11 Horvath EP Jr. Technical manual 77-1. Norfolk, Virginia 23511: Navy Environmental Health Center, 1977.

12 Colardyn F, Van der Straeten M, Lamont H, Van Peteghem TH. Acute inhalation-intoxication by combustion of polyvinyl chloride. Int Arch Occup Environ Health 1976;18:121-7.

13 Tsuchiya Y, Sumi K. Thermal decomposition products of polyvinyl chloride. Journal of Applied Chemistry 1967; 17:364-6.

14 Napier DH. Hazardous materials and the gases they produce. Med Sci Law 1977;17:83-90. 